\title{
ANALISIS YURIDIS PERJANJIAN KERJASAMA ANTARA NOTARIS DENGAN BANK DITINJAU DARI UNDANG-UNDANG NOMOR 2 TAHUN 2014 TENTANG JABATAN NOTARIS DAN KODE ETIK NOTARIS
}

\author{
Oleh: Rosida Diani, SH, MH dan Dr. Azwar Agus, SH, M.Hum. \\ (Dosen FH Universitas Tamansiswa Palembang)
}

\begin{abstract}
ABSTRAK
Dalam perkembangannya profesi notaris sangat dibutuhkan didunia perbankan terutama dalam hal pembuatan akta perjanjian kredit perbankan yang melibatkan nasabah dan bank, guna menjamin kebenaran dari isi yang dituangkan dalam perjanjian krredit perbankan tersebut, supaya secara publik kebenarannya tidak diragukan lagi. Perjanjian kerjasama antara bank dan notaris tidak memenuhi syarat sahnya perjanjian berdasarkan Pasal 1320 KUH Perdata mengenai suatu sebab yang tidak terlarang, karena berdasarkan analisis lebih mendalam dan penelitian terhadap substansi dari pelaksanaan perjanjian kerjasama antara bank dan notaris terdapat pelanggaran Undang-Undang Jabatan Notaris dan Kode Etik Notaris.
\end{abstract}

\section{A. Latar Belakang}

Indonesia adalah negara yang meletakkan hukum sebagai kekuasaan tertinggi berlandaskan Pancasila dan Undang Undang Dasar 1945 telah memberikan jaminan bagi seluruh warga negaranya untuk mendapatkan kepastian, ketertiban dan perlindungan hukum yang berintikan pada kebenaran dan keadilan. Jaminan kepastian, ketertiban, dan perlindungan hukum tersebut tentu membutuhkan upaya konkret agar terselenggaranya pertanggungjawaban negara bagi kemakmuran seluruh rakyat Indonesia.

Notaris adalah pejabat umum yang berwenang untuk membuat akta otentik dan kewenangan lainnya. Notaris adalah salah satu pihak yang berwenang untuk membuat akta otentik mengenai semua perbuatan, perjanjian dan penetapan yang diharuskan oleh suatu peraturan umum atau oleh yang berkepentingan dikehendaki untuk dinyatakan dalam suatu akta otentik, menjamin kepastian tanggalnya, menyimpan minutanya dan memberikan grosse, salinan dan kutipannya, sepanjang pembuatan akta itu oleh suatu peraturan umum tidak juga ditugaskan atau dikecualikan kepada pejabat lain atau orang lain.

Jasa notaris sebagai pembuat akta otentik sangat dibutuhkan dalam kegiatan usaha perbankan, salah satunya adalah dalam pembuatan akta perjanjian kredit perbankan tersebut supaya secara publik kebenarannya tidak perlu diragukan lagi. 
Arti penting dari sebuah profesi notaris adalah bahwa karena undang-undang notaris diberikan wewenang untuk mennciptkan alat pembuktian yang sempurna, yaitu dalam pengertiannya bahwa apa yang dimuat dalam suatu akta otentik oleh notaris dianggap benar.

Suatu akta otentik ialah suatu akta yang di dalam bentuk yang ditentukan oleh undang-undang, dibuat oleh atau dihadapan pejabat umum yang berkuasa untuk itu ditempatkan dimana akta dibuatnya. ${ }^{49}$ Akta otentik pada hakikatnya memuat kebenaran formal sesuai dengan apa yang diberitahukan para pihak kepada Notaris. Namun notaris mempunyai suatu kewajiban untuk memastikan bahwa apa yang termuat dalam Akta Notaris telah dimengerti dan sesuai dengan kehendak dari para pihak, serta memberikan informasi, baik terhadap perundang-undangan yang terkait bagi para pihak penandatangan akta.

Sebagai pejabat umum, seorang notaris diharuskan memiliki kepribadian:

1. Dalam melaksanakan tugasnya harus dijiwai Pancasila, sadar dan taat kepada hukum peraturan jabatan notaris, sumpah jabatan notaris, kode etik notaris, dan berbahasa Indonesia yang baik.

2. Memiliki perilaku professional dan ikut serta dalam pembangunan nasional, terutama sekali dalam bidang hukum.

3. Berkepribadian baik dan menjunjung tinggi martabat dan kehormatan notaris, baik di dalam maupun di luar tugas jabatannya. ${ }^{50}$

Kode etik notaris sebagai suatu ketentuan yang mengatur tingkah laku notaris dalam melaksanakan jabatannya, juga untuk mengatur hubungan sesame rekan notaris. Kode etik notaris sangat diperlukan untuk menjaga kualitas pelayanan hukum kepada masyarakat. Pada hakekatnya kode etik notaris merupakan penjabaran lebih lanjut dari apa yang diatur dalam Undang-Undang Jabatan Notaris. Dalam kehidupan bermasyarakat diperlukan suatu profesi dimana seseorang dapat menyelesaikan masalah-masalah hukum yang dihadapinya yaitu salah satunya dengan menghadap kepada seorang notaris.

Notaris merupakan suatu profesi kepercayaan dan berlainan dengan profesi penasehat hukum, dimana notaris dalam menjalankan jabatannya kepada yang bersangkutan dipercaya untuk membuat alat bukti yang mempunyai kekuatan autentik. Dalam perkembangannya profesi notaris sangat dibutuhkan didunia perbankan terutama dalam hal pembuatan akta perjanjian kredit perbankan yang melibatkan nasabah dan bank, 
guna menjamin kebenaran dari isi yang dituangkan dalam perjanjian krredit perbankan tersebut, supaya secara publik kebenarannya tidak diragukan lagi.

Dalam hal perjanjian kredit, kedudukan bank sebagai kreditur dan nasabah sebagai debitur tidak akan pernah seimbang. Perjanjian kredit pada bank pada umumnya berbentuk perjanjian baku, perjanjian yang konsep janji tertulis yang disusun tanpa membicarakan isinya dan lazimnya dituangkan dalam sejumlah perjanjian yang sifatnya tertentu.

Notaris sebagai pejabat publik dituntut profesionalitasnya salah satunya dalam hal menjembatani kepentingan debitur dan kreditur dalam pembuatan akta perjanjian kredit, namun kenyataannya sikap profesionalitas tersebut berhadapan dengan tuntutan dunia perbankan, yaitu efisiensi dalam prosedur perbankan dan keamanan dalam pemberian kredit, sehingga dalam prakteknya lembaga perbankan cenderung menggunakan perjanjian baku dalam perjanjian kredit. Dan perundang-undangan yang mengatur tentang jabatan notaris telah dibuat sedemikian rupa agar dapat menjamin tentang otentisitame akta-akta yang dibuat dihadapannya. Untuk itulah sebuah peraturan kode etik dalam sebuah Ikatan Notaris sengaja dibuat untuk menjaga kualitas pelayanan kepada publik.

Berdasarkan latar belakang masalah yang telah dijabarkan tentu dapat dilihat banyak hal yang perlu dibenahi, maka dapat ditentukan hal-hal yang akan menjadi rumusan masalah, yaitu: Bagaimanakah kedudukan perjanjian kerjasama antara Notaris dengan Bank ditinjau dari Undang-Undang Nomor 2 Tahun 2014 tentang Jabatan Notaris dan Kode Etik Notaris?

\section{B. Pembahasan}

Notaris sebagai pejabat umum memiliki peranan sentral dalam menegakkan hukum di Indonesia, karena selain kuantitas notaris yang begitu besar, notaris dikenal masuk kelompok elit berarti notaris merupakan suatu komunitas ilmiah yang secara sosiologis, ekonomis, politis serta psikologis berada dalam stratifikasi yang relative tinggi di antara masyarakat pada umumnya.

Dasar utama dari suatu profesi notaris ini adalah kepercayaan dan sebagai suatu komunitas elit demikian, para professional yang tergabung dalam komunitas tersebut menanggung amanah yang berat atas kepercayaan yang diembankan kepadanya. ${ }^{51}$

51 Abdul Ghofur Anshori, Lembaga Kenotariatan Indonesia Perspektif Hukum dan Etika, UII Press, Yogyakarta, 2009, hlm. 1 
Notaris sebagai sebuah profesi yang mulia memegang peranan penting dalam kehidupan bermasyarakat, terutama masyarakat modern yang menghendaki adanya pendokumentasian suatu peristiwa hukum atau perbuatan hukum tertentu yang dilakukan oleh subjek hukum baik dalam arti subjek hukum berupa orang maupun subjek hukum dalam arti badan hukum.

Undang-Undang Jabatan Notaris (UUJN) dan Kode Etik Notaris merupakan acuan bagi notaris dalam berperilaku, apa saja yang boleh dan tidak boleh dilakukan oleh notaris, Pasal 1 Undang-Undang Jabatan Notaris menyatakan bahwa notaries adalah Pejabat Umum yang berwenang untuk membuat akta otentik dan kewenangan lainnya sebagaimana dimaksud dalam Undang-Undang, dan dalam Pasal 16 ayat (1) (a) UUJN dituliskan bahwa dalam menjalankan jabatannya, notaries berkewajiban bertindak jujur, saksama, mandiri, tidak berpihak, dan menjaga kepentingan pihak yang terkait dalam perbuatan hukum. Notaris adalah pejabat umum yang diberikan oleh Undang-Undang, wewenang untuk menjalankan sebagian kewenangan negara atau pemerintah dalam hal hukum keperdataan. Sebagai pejabat umum notaris juga merupakan profesi yang tunduk pada aturan yang ditentukan dalam semua peraturan perundang-undangan yang berlaku, sumber hukum yang lain, seperti asas-asas hukum, antara lain: Asas Moralitas, Asas Kepatutan, dan Asas Kebiasaan, serta kode etik, AD/ART profesi, yang mana aturan tersebut telah disepakati bersama, melekat dan mengikat semua notaris, agar seorang notaris mempunyai perilaku yang baik, menghormati sesama notaris, taat hukum, selalu menjaga harkat, martabat, integritas notaris, dan organisasi, agar roda organisasi menjadi teratur, tertib dan baik, pelayanan kepada masyarakat, anggota, meningkat dan dapat mempertanggungjawabkan kepemimpinannya kepada public, bangsa, negara dan tidak lupa Allah SWT Tuhan Yang Maha Esa.

Ada beberapa asas atau nilai yang harus dijaga seorang notaris yaitu: ${ }^{52}$

1. Jujur, seksama, mandiri, tidak berpihak dan menjaga kepentingan semua pihak yang terkait ddalam perbuatan hukum.

2. Memberikan pelayanan kepada semua sesuai dengan UU, kecuali ada alasan untuk menolaknya.

3. Merahasiakan segala sesuatu mengenai akta.

4. Unsur professional lain "good faith", taat pada kebenaran.

52http://www.jimlyschool.com/read/news/358/kepemimpinan-notaris-yang-beretika-danbertanggungjawab/diakses tanggal 10 Januari 2016 
Notaris juga sebagai pejabat umum yang menjalankan sebagian fungsi public dari negara, khususnya di bidang hukum perdata. Sebagai pejabat umum notaris haruslah: ${ }^{53}$

1. Berjiwa Pancasila

2. Taat kepada hukum, sumpah jabatan, kode etik notaris

3. Berbahasa Indonesia yang baik

Sebagai professional notaris:

1. Memiliki perilaku notaris yang baik, dan patut diteladani

2. Ikut serta pembangunan nasional di bidang hukum

3. Menjunjung tinggi kehormatan dan martabat sebagai notaries.

Notaris juga merupakan profesi yang menjalankan sebagian kekuasaan negara di bidang hukum privat dan mempunyai peran penting dalam membuat akta otentik yang mempunyai kekuatan pembuktian sempurna dan oleh karena jabatan notaris merupakan jabatan kepercayaan, bukan jabatan politik, maka seorang notaris harus mempunyai perilaku yang baik, jangan sampai menyalahgunakan jabatannya tersebut hanya untuk kepentingan pribadi. Perilaku notaris yang baik dapat diperoleh dengan berlandaskan pada semua peraturan perundang-undangan, asas-asas hukum, dank ode etik. Seorang notaris hendaklah selalu berpegang pada ketiga hal tersebut di atas baik dalam menjalankan jabatannya juga di luar menjalankan jabatannya, antara lain: ${ }^{54}$

1. Memiliki moral, akhlak serta kepribadian yang baik;

2. Menghormati dan menjunjung tinggi harkat dan martabat jabatan notaris;

3. Menjaga dan membela kehormatan perkumpulan;

4. Bertindak jujur, mandiri, tidak berpihak, penuh rasa tanggungjawab berdasarkan perundang-unddangan dan isi sumpah jabatan notaris;

5. Meningkatkan ilmu pengetahuan yang telah dimiliki tidak terbatas pada ilmu pengetahuan hukum dan kenotariatan.

6. Mengutamakan pengabdian kepada kepentingan masyarakat dan negara.

Perjanjian kerjasama antara bank dan notaries sebenarnya sangat mengganggu kredibilitas notaris itu sendiri. Berdasarkan penelitian yang dilakukan oleh penulis, perjanjian antara bank dan notaris membuat notaris tidak mandiri dan cenderung berpihak kepada bank tempat ia melakukan perjanjian kerjasama, padahal notaris seharusnya bersifat netral dan menjaga kepentingan masyarakat tanpa ada keberpihakan. 
Sangat disayangkan sebenarnya Majelis Pengawas Wilayah Notaris tidak mengetahui adanya perjanjian kerjasama antara bank dengan notaris secara tertulis, karena tentunya dengan tidak mengetahui adanya perjanjian tertulis antara bank dan notaris bisa dinilai bahwa Majelis Pengawas belum bekerja secara maksimal dalam mengawasi notaris. Ketidakmaksimalan pengawasan memang terkendala oleh masalah geografis, yang jarak antara kabupaten satu ke kabupaten lain mesti ditempuh dalam waktu lama.

Perjanjian kerjasama yang dilakukan oleh notaris merupakan ranah perdata karena masalah perjanjian, jika kedua belah pihak telah setuju dan sepakat untuk mengikatkan dirinya maka perjanjian itu mengikat dan berlaku sebagai undang-undang bagi kedua belah pihak, tentunya dengan memperhatikan bahwa perjanjian yang dilakukan itu tidak melanggar ketentuan undang-undang yang berlaku.

Perlu diketahui bahwa perjanjian kerjasama seperti tersebut di atas, tidak dilakukan oleh semua notaris. Terdapat pula notaris yang tidak membuat perjanjian kerjasama sebagaimana tersebut di atas, namun bank tetap menggunakan jasanya dalam hal pembuatan akta otentik ataupun pelayanan jasa notaris lainnya. Bahkan bagi notaris yang telah memiliki reputasi, apabila bank ternyata tetap memberikan perjanjian yang demikian dapat bertentangan dengan undang-undang jabatan Notaris dan Kode Etik Notaris, serta dapat mempengaruhi keberpihakan notaries dalam membuat akta otentik. Hal tersebut karena berdasarkan informasi dari notaris, para pihak yang menghadap notaries pada umumnya adalah pihak yang buta hukum, sehingga mereka tidak tahu akta apa yang harus dibuat dan kadangkala keinginan para pihak belum tepat secara hukum.

Larangan ini timbul karena dalam praktik terdapat beberapa ketentuan yang diatur dalam perjanjian kerjasama menyimpang dari kaedah, nilai dan aturan dalam ketentuan Kode Etik Notaris maupun Undang-Undang Jabatan Notaris, serta dapat menimbulkan sikap ketidakmandirian dan menghilangkan sikap ketidakberpihakan notaris kepada salah satu klien. Beberapa ketentuan Undang-Undang Jabatan Notaris dan Kode Etik Notaris yang dilanggar sehubungan dengan perjanjian kerjasama terjadi dalam praktik sebagai berikut:

1. Pasal 4 angka 5 Kode Etik Notaris menyatakan notaris dan orang lain yang memangku dan menjalankan jabatan notaris dilarang menandatangani akta yang proses pembuatan minutanya telah dipersiapkan oleh pihak lain. Maksud yang terkandung dalam aturan ini adalah bahwa notaris tidak boleh menandatangani akta yang proses pembauatannya telah dipersiapkan oleh notaris lain atau pihak tertentu, seolah-olah akta tersebut buatannya sendiri. Tujuan dari aturan ini agar notaris dalam proses pembuatan minuta 
akta terlebih dahulu memperlihatkan ketentuan hukum yang ada dalam akta serta memenuhi unsur perlindungan bagi para pihak (ketertidakpihakkan). Dapat diketahui apakah rumusan akta tersebut telah sesuai dengan peraturan perundang-undangan, dan memeriksa apakah sebuah perjanjian yang dibuat telah memenuhi kaidah perjanjian yang benar dan tidak merugikan salah satu pihak. Pada kenyataannya notaris kerap diminta bank untuk membuat perjanjian kredit dibawah intervensi bank. Intervensi itu tampak ketika klausul yang dituangkan dalam perjanjian lebih banyak ditentukan oleh bank. Bank akan meminta notaris membuat akta perjanjian terutama akta Perjanjian Kredit berpedoman kepada model Perjanjian Kredit dari bank yang bersangkutan, bahkan terkadang terhadap akta Perjanjian Kredit memiliki kesamaan secara keseluruhan dengan rumusan akta Perjanjian Kredit yang telah diadakan bank sebelumnya. Beberapa klausul yang diminta untuk dicantumkan dalam perjanjian kredit seperti perubahan suku bunga yang sewaktu-waktu bisa berubah secara sepihak tanpa pemberitahuan terlebih dahulu kepada nasabah debitur. Hal ini menunjukkan tidak ada jaminan keamanan informasi yang diberikan oleh bank sebagai pelaku usaha dalam penggunaan jasa-jasa yang diberikan kepada nasabah debitur. Klausul ini terindikasi sebagai klausul eksenorasi karena adanya perlindungan bank sebagai pelaku usaha untuk mengurangi atau mengalihkan risiko yang mungkin timbul kemudian hari.

Menurut J Satrio berpendapat bahwa klausula eksonerasi sebagai suatu klausula dalam suatu perjanjian dan karenanya disepakati oleh para pihak bila mana ditetapkan adanya pembebasan atau pembatasan dari tanggungjawab tertentu, yang secara normal menurut hukum seharusnya menjadi tanggungjawabnya" "55. Selanjutnya klausul berupa syarat-syarat umum kredit yang menyatakan "tterhadap perjanjian pengakuan hutang ini dan segala akibatnya berlaku pula syarat-syarat umum perjanjian penjaminan dan kredit bank yang telah disetujui oleh dan mengikat pengambil kredit atau yang berhutang serta merupakan satu kesatuan yang tidak terpisahkan dari perjanjian pengakuan hutang ini, sekalipun syarat-syarat tersebut dilampirkan atau tidak dilampirkan daalam perjanjian pengakuan hutang ini". 56

Berdasarkan Pasal 1320 ayat (3) KUH Perdata "adanya suatu hal tertentu" yang berarti bahwa harus telah ada terlebih dahulu suatu hal yang diperjanjikan itu. Pencantuman di dalam suatu perjanjian kredit klausul bahwa nasabah debitur tunduk

55 J. Satrio, Hukum Perikatan, Perikatan Yang Lahir Dari Perjanjian, Citra Aditya Bakti, Bandung, 1995, hlm. 119

56 Ibid, hlm. 119 
kepada "syarat-syarat baik yang dilampirkan maupun tidak dilampirkan dalam perjanjian pengakuan hutang" jelas suatu hal yang akan diperjanjikan itu belum dapat diketahui karenanya petunjuk dan peraturan bank masih akan ditentukan kemudian oleh bank. Sedangkan apabila suatu hal tertentu itu ternyata di kemudian hari menyangkut barang, maka berdasarkan pasal 1333 KUH Perdata barang itu paling sedikit sudah harus diketahui jenisnya.

Dari bunyi klausul di atas maka tidaklah mungkin untuk mengetahui jenis barang dari barang itu karena hal itu masih akan ditentukan kemudian oleh bank. Pada akhirnya nasabah yang dibebankan dalam perjanjian itu karena memiliki posisi tawar yang lemah, sedangkan notaris tidak bisa berbuat banyak karena sudah terikat perjanjian dengan bank. Seharusnya notaris menolak, apabila pihak bank memaksa untuk membuat suatu perjanjian atau akta otentik lainnya yang merugikan pihak nasabah karena bertentangan dengan aturan hukum. Sesuai dengan wawancara penulis dengan Notaris Ibu Leanni Bharline yang menyatakan: "Pemerintah dalam hal ini telah memberikan perlindungan kepada nasabah selaku konsumen perbankan melalui Undang-Undang Nomor 8 Tahun 1999 tentang Perlindungan Konsumen. Pasal 18 UU Nomor 8 Tahun 1999 mengatur tentang ketentuan pencantuman klausul baku yang bertentangan dengan Undang-Undang Perlindungan Konsumen, maka nasabah sebagai konsumen yang menggunakan jasa perbankan dapat menggugatnya atau lapor ke BPSK (Badan Penyelesaian Sengketa Konsumen) dan notaris yang memaksakan diri untuk membuat perjanjian atau akta otentik yang bertentangan dengan hukum positif di Indonesia harus bertanggungjawab secara moral dan hukum”.

Menurut hemat penulis, ketika bank yang memiliki posisi tawar yang lebih kuat dibandingkan nasabah, sehingga bank dapat memaksa kehendaknya kepada pihak yang lemah (nasabah) untuk mengikuti syarat-syarat perjanjian yang diberikan kepadanya, seyogianya notaris perlu campur tangan untuk melindungi pihak nasabah dengan cara membuat akta perjanjian kredit yang tidak hanya melindungi kepentingan-kepentingan dari bank saja, namun juga melindungi kepntingan-kepentingan nasabah debitur.

2. Pasal 4 angka 13 Kode Etik Notaris menyatakan, notaris dan orang lain yang memangku dan menjalankan jabatan notaris dilarang : membentuk kelompok sesame rekan sejawat yang bersifat ekslusif dengan tujuan untuk melayani kepentingan suatu instansi atau lembaga, apalagi menutup kemungkinan bagi notaries lain untuk berpartisipasi. 
Sebagai pejabat umum, notaris memiliki perilaku professional. Salah satunya dalam memberikan pelayanan terhadap pihak yang membutuhkan jasa-jasa notaris, bertindak secara proporsional tidak tergantung pada besar kecilnya bayarannya. Pasal 4 angka 13 Kode Etik Notaris di atas menegaskan kepada para notaris bahwa dalam menjalankan jabatannya, tidak boleh memberikan pelayanan secara ekslusif kepada suatu instansi atau lembaga terlbih lagi membentuk kelompok yang dapat menghalangi masuknya notaries lain masuk dalam instansi atau lembaga tersebut. Pelayanan yang ekslusif tersebut dapat diketahui dalam perjanjian kerjasama antara bank denga notaris.

3. Pasal 4 angka 10 Kode Etik Notaris menyatakan, notaris dan orang lain yang memangku dan menjalankan jabatan notaries dilarang: menetapkan honorarium yang harus dibayar oleh klien dalam jumlah yang lebih rendah dari honorarium yang telah ditetapkan perkumpulan.

Dalam beberapa kasus, tidak jarang pada saat penawaran kerjasama antara bank dengan notaris, notaris melakukan negosiasi honor, layaknya pekerja atau pebisnis pada umumnya. Bahkan kadang notaris membanting honornya demi mendapatkan pekerjaan pembuatan akta di bank tersebut.

Menurut hemat penulis, penetapan honor yang lebih rendah dianggap dapat menciptakan persaingan yang tidak sehat di antara para notaris. UUJN secara tersirat melarang timbulnya persaingan tidak sehat sebagaimana tertulis dalam penjelasan Pasal 17 huruf (a) yang menyatakan bahwa larangan dalam ketentuan tersebut dimaksud untuk memberikan kepastian hukum kepada masyarakat dan sekaligus mencegah terjadinya persaingan tidak sehat antar notaris dalam menjalankan jabatannya. Kode Etik Notaris sendiri secara tegas melarang perbuatan yang menimbulkan persaingan tidak sehat antar notaris sebagaimana diatur dalam Pasal 4 angka 9 Kode Etik Notaris, yaitu: "Notaris dan orang lain yang memaangku dan menjalankan jabatan Notaris dilarang melakukan usaha-usaha baik langsung maupun tidak langsung yang menjurus kearah timbulnya persaingan yang tidak sehat dengan sesama rekan Notaris."

Imbas dari persaingan yang tidak sehat berdampak pada penurunan harkat dan martabat notaries itu sendiri di mata masyarakat. Oleh karena itu penentuan honorarium yang diserahkan kepada perkumpulan notaries yaitu Ikatan Notaris Indonesia (INI) menetapkan besar honorarium bagi anggotanya.

4. Pasal 4 angka 4 Kode Etik Notaris dituliskan bahwa notaris dan orang lain yang memangku dan menjalankan jabatan Notaris dilarang: bekerjasama dengan biro 
jasa/orang/badan hukum/ yang pada hakekatnya bertindak sebagai perantara untuk mencari atau mendapatkan klien.

Bank yang telah memiliki notaris rekanan tidak ingin menggunakan jasa notaris lain selain notaris rekanan. Apabila dikaji lebih jauh, tindakan bank dalam hal ini sebagai perantara untuk mencari atau mendapatkan klien, sehingga notaris dapat dikategorikan telah bekerjasama dengan bank untuk mendapatkan klien berupa nasabah bank itu sendiri.

\section{Kesimpulan.}

Dari pembahasan tersebut diatas, maka penulis menarik beberapa kesimpulan sebagai berikut: Perjanjian kerjasama antara bank dan notaris tidak memenuhi syarat sahnya perjanjian berdasarkan Pasal 1320 KUH Perdata mengenai suatu sebab yang tidak terlarang, karena berdasarkan analisis lebih mendalam dan penelitian terhadap substansi dari pelaksanaan perjanjian kerjasama antara bank dan notaris terdapat pelanggaran Undang-Undang Jabatan Notaris dan Kode Etik Notaris seperti yang sudah penulis bahas dalam skripsi ini, yang mengakibatkan perjanjian batal demi hukum.

\section{DAFTAR PUSTAKA}

Abdul Ghofur Anshori, Lembaga Kenotariatan Indonesia Perspektif Hukum dan Etika, UII Press, Yogyakarta, 2009.

Habib Adjie, Sanksi Perdata dan Administratif Terhadap Notaris Sebagai Pejabat Publik, Refika A35ditama, Bandung, 2009.

, Hukum Notaris Indonesia, Refika Aditama, Bandung, 2014,

J. Satrio, Hukum Perikatan, Perikatan Yang Lahir Dari Perjanjian, Citra Aditya Bakti, Bandung, 1995

R. Subekti, Hukum Perjanjian, Intermassa, Jakarta, 1991

Suhrawardi K Lubis, Etika Profesi Hukum, Rineka Cipta, Jakarta, 2014.

Ustad Adil, Mengenal Notaris Syariah, Citra Aditya Bakti, Bandung, 2011 